\title{
Encouraging Consumers to Make Online Purchases Using Mobile Applications, How to Keep them in Touch with E-Services Providers?
}

\author{
https://doi.org/10.3991/ijim.v14i17.16599 \\ Ahmad Zamil ${ }^{(凶)}$ \\ Prince Sattam bin Abdulaziz University, Al-Kharj, Saudi Arabia \\ am.zamilepsau.edu.sa \\ Ibrahim A. Abu-AlSondos \\ Applied Science University, Eker, Bahrain \\ Anas A. Salameh \\ Prince Sattam bin Abdulaziz University, Al-Kharj, Saudi Arabia
}

\begin{abstract}
Progress in wireless technology has raised the number of people using mobile devices and stimulated the accelerated evolution of online shopping carried with these devices. However, today many corporations are making significant investments to take benefit of the new business opportunities given by internet technology, research on m-online shopping proposes potential customers may or may not adopt mobile shopping despite of their availability and benefits. Thus, this study identifies the key factors that influence customer intention to make online mobile shopping. This research investigates the dimensions of mobile shopping service based on online shoppers' expectations and perceptions. This research developed a conceptual framework for examining the role of the perceived usefulness, perceived ease of use and trust in order to determining customers' intention to use mobile shopping. Data were obtained from 212 students of business administration college, who conducted a mobile online shopping process, the sample was tested on the analysis model using (SEM-PLS). The results strongly support the proposed model in predicting consumer intention to use mobile shopping. the major findings of this study found positive relationship among perceived usefulness, perceived ease of use and trust association with intention to use m-online shopping. The current study model and its findings could present a rigorous basis for understanding customers' attitude for mobile shopping contexts.
\end{abstract}

Keywords-Mobile online shopping, Consumers believe, Consumer attitude, M-services.

\section{Introduction}

Globalization has contributed to complete development in electronic marketing. In the prior decade, the technological transition has maximized organizations markets. 
Technology has enhanced marketing performance such as mobile online shopping and marketing(Alkafagi, Salameh, \& Abu-AlSondos, 2019). Retailers have developed strategies in order to meet online shoppers' demands(Algharabat, Zamil, \& Vasista, 2015); they focused on studying customer behavior for mobile online shopping field to discover customer attitudes toward mobile online buying process. The researchers investigated customers' behavior towards mobile online shopping and what factors may influence customers to make online purchasing process(Asmara, Sis, \& Yusuf, 2020; Sultan \& Uddin, 2011). The global number of online users increased from 1,32 billion in 2014 to 1,92 billion in 2019.By 2021, over than 2,14 billion people around the world are expected to shop online. The growth in internet usage is connected to the growth in the use of the broadband infrastructure with improvements in consumer behavior toward mobile online shopping(Areiqat, Mahrakani, Zamil, \& Abu-Rumman, 2019). Millions of applications for e-commerce sites has been developed around the world for goods and services online purchase(Salameh \& Hassan, 2015). Today online shopping has helped in increasing customers satisfaction and convenience(Abu-AlSondos \& Salameh, 2020). Nowadays, E-commerce has helped consumers to buy products and services at any time any place without visiting the physical store (Minnaar, Mototo, \& Chuchu, 2020; Omonedo \& Bocij, 2014). This study has explained three key factors that impact online shopping. online retailers took advantages to expand their online companies. Mobile online shopping can be defined as an electronic commerce process that allows consumers to buy products and services directly via the internet from a seller using a browser(Salameh, Ahmad, Zulhumadi, \& Abubakar, 2018).Customers can find attractive products by visiting the retailer website(Zamil, 2011). Online shopping websites evokes the physical analogy between consumers and retailers, this called business-to-consumer shopping (B2C)(Akkucuk \& Esmaeili, 2016). When a web store is developed to allow firms to purchase from other firms it is called business to business (B2B)(Biedenbach \& Marell, 2010). In India, the most favored payment method is cash on delivery, which makes up $75 \%$ of the electronic retail business. Demand for foreign customer products is growing extensively faster than domestic supplies from licensed distributors and e-commerce offers. Indian Institute of E-Commerce is predicted to generate $\$ 100$ billion of e-commerce revenue, of which $\$ 35$ billion is generated by ecommerce mode, in 2021(Santhi \& Gopal, 2018).

\section{$2 \quad$ Literature Review}

\subsection{Studies related}

Kibet (2016) proposed that the main goal for estimating customer behavior for online shopping in the province of Nairobi, Kenya include choosing, gathering and reviewing the adopted system, an acceptable system from previous research studies. The ultimate purpose was to recommend a framework based on the study results. The methodology of analysis used in this research was deductive and explicative in paper and electronic form for data, collection a standardized questionnaire was administered. The sample population was 384 and the process of random sampling was chosen to receive the 
respondents. The data have been examined using statistical software and results shown in the hypotheses testing frequency, percentages and partial lower square model. 356 respondents get complete answers from the 384 questionnaires distributed, which was used for data analysis. Results reveal that $97.2 \%$ of respondents had shopped online previously, and $2.8 \%$ had never shopped online. The study found that the data obtained supported 10 out of 13 hypothesized ties identified in the conceptual framework. The outcomes of this research presented a favorable evaluation of the behavior of online customers and the use of technology in e-commerce fields research in Kenya. The research suggests more longitudinal study to examine customer behavior towards online buying to assess the number of services and goods, and the frequency of buying spent over a while. Selvamani and Vidya (2019)used a descriptive research study and a referencing method for snowballs is adopted. 412 samples were obtained, including 188 samples for the district of Erode and 224 for the district of Trichy. The outcomes explained that the website consumers are satisfied with all company dimensions, and there have been important links to the level of awareness in online buying such as educational skills, information about online shopping, number of online transactions and favored mode of payment. Results: Chi-square analysis exhibits that knowledge factors for online shopping have been correlated with awareness of shopping online for years, educational abilities, number of online shopping and favorable payment method. Bin Dost, Illyas, and Abdul Rehman (2015)examines the association between factors influencing costumers-buying attitude towards online shopping. This research focuses on the impact of five important variables that were derived from literature such as time, variety of products, trust, privacy and comfort. customer buying attitude (depending on the variable) to determine how customer buying attitude reveals online shopping trends. The statistical analysis of the data reflects that trust and convenience are considerably impactful on whether people want to buy online or through mortar and brick stores, while privacy has insignificant influence on buying behaviors.

\subsection{Perceived usefulness}

Perceived usefulness means that the internet is considered a useful tool in online shopping by online consumers(Davis, 1989). Utility is seen to have the highest impact on the intention of consumers to buy online (Belanche, Casaló, \& Guinalíu, 2012; Hausman \& Siekpe, 2009; Wongkhamdi, Cooharojananone, \& Khlaisang, 2020). According to Rosqvist and Hiselius (2016)If the Internet is viewed by online consumers as a useful tool for shopping online, they can do more shopping online. In addition, research in United Kingdom has been carried out and a questionnaire has been distributed to 500 online consumers to learn the factors affecting their online shopping. The findings have shown that the majority of online customers who replied to the questionnaires think they would complete their shopping tasks more easily using the Internet and decide better on purchases. In total, 89 percent agreed that the usefulness perceived was one of the main factors influencing online shops(Kevin, 2019). Hence, researcher's hypothesis as the following:

- $\mathrm{H}_{1}$ : There is a positive association between usefulness towards mobile online shopping. 


\subsection{Perceived ease of use}

The consumer's perception of ease of use is that communication with the online retailer via their websites is easier and online shopping takes little effort(Abu-Shanab, 2017). The perceived simplicity of shopping online is about how easy it is(Pratyaksa, 2015). The intention of the user to shop online affects him greatly. Long loading time is a part of the unfavourability of many e-commerce websites. If the formulas produced are weak, potential buyers may lose focus on their purchases. Such impediments reduce the illusion that online shopping is easy to use and lead online shoppers to develop a negative attitude towards online shopping and to avoid shopping online(Sultan \& Uddin, 2011). Most customers agree that it is easier to use the internet to buy products or services. Online retailers should also understand how easily they can offer their goods or services online when selling online. Hence, researcher's hypothesis as the following:

- $\mathrm{H}_{2}$ : There is a positive association between ease of use towards mobile online shopping.

\subsection{Trust}

It relates to consumer's confidence for online shopping and their belief that online sites will present fair prices, correct information for services and products, preserve customer confidentiality, and manage transaction information and credit card safely(Abu-Shanab, 2014). Hence, it is very important to build customers trust for online retailers and customers that are not able to see each other physically(Azmi, Ang, \& Talib, 2016).

How can you build consumer trust? According to Kevin (2019)the website must contain adequate information with details about services and products.

- Communicate more with customers.

- Allow customers to give feedback.

- Providing customers with sufficient goods and services.

- Be honest about the availability of goods.

- Provide secure online payments.

If no one is reliable, customers will not make online purchasing for product or services. Online customers prefer fair online shops that guard their privacy and provide sufficient services and products to them(Belanger, Hiller, \& Smith, 2002). Hence, researcher's hypothesis as the following:

- $\mathrm{H}_{3}$ : There is a positive association between Trust towards mobile online shopping. The research model for proposed hypothesis can be shown in Fig. 1 as follows. 


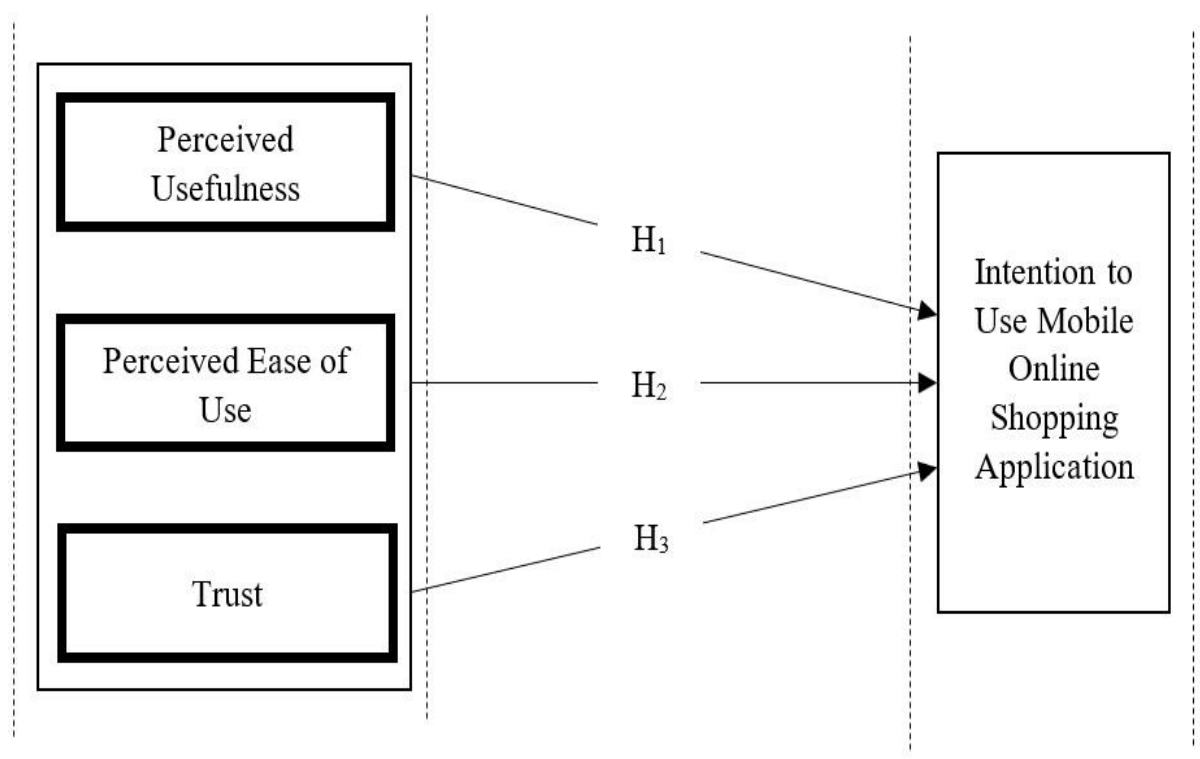

Fig. 1. Research Model

\section{Methodology}

\subsection{Development of instrument}

To get a better understanding of the main factors affecting customers to make online shopping, the factors influence customers on the three identified online shopping services - Perceived Usefulness, Perceived Ease of Use, and Trust. For each of the services, items were extracted from the literature. Furthermore, items associated with each of the factors considered earlier in the hypothesis section were drawn from the literature. To assure content and face validity, all the items were discussed with two specialists and three online shoppers' customers. This guided the modification and addition of some of the items. The final list for online buying services under the four elected categories is shown in Table I. Respondents were asked to assess their engagement level over the past six months for each item on the three online shopping services using a five-point Likert scale with $1=$ never to 5=always. Moreover, respondents were asked to assess each item using a five-point Likert scale with $1=$ strongly disagree to $5=$ strongly agree. The study instrument also captured sociodemographic and customer attitude towards online shopping services usage-related questions.

\subsection{Data collection and sampling}

The sample of the investigation was an online shopper using websites or even mobiles. Data were gathered using a convenience sampling method which is face to face, the survey was distributed to students of business administration college, whether 
students are graduated or still on college to ensure the capture of data from customers belonging to four main cities. A total sample of 212 data was available for additional investigation. The data consisted of $66.22 \%$ of people up to the age of 30 years and $53.42 \%$ males. Moreover, there was a fair split of graduated student's vs current students $(41.02 \%)$. Approximately, $70 \%$ of the respondents were single.

\section{$4 \quad$ Analysis and Result}

\subsection{The construct validity}

The Construct Validity relates to the degree to which the items generated to measure a construct which can properly measure the concept they were designed to measure(Hair, Anderson, Babin, \& Black, 2010). To be more precise, the complete items designed to measure a variable must load larger on their respective variables than their loadings on other variables. The outcomes show the construct validity of the measurements used as shown in 2 ways. First, the items present high loading on their respective constructs when contrasted to other constructs. Second, the item loadings were sufficiently loading on their particular constructs establishing the construct validity correlated to the measurements practiced in this research as described in both Table 1 (Chow \& Chan, 2008).

\subsection{Convergent validity}

As described in Table 2 it can be seen that the composite reliability values varied from 0.763 to 0.865 passes the recommended value of 0.7 (Fornell \& Larcker, 1981; Hair et al., 2010). Also, the AVE (average variances extracted) values which varied from 0.515 to 0.602 show a good level of construct validity correlated to the utilized measurements (Barclay, Higgings, \& Thompson, 1995). The convergent validity of the residual model is confirmed from these outcomes. 
Table 1. Construct validity

\begin{tabular}{|l|c|c|c|c|c|}
\hline \multicolumn{1}{|c|}{ Variables } & Items & PU & PEU & TR & CMOS \\
\hline \multirow{4}{*}{ Perceived Usefulness } & PU1 & $\mathbf{0 . 6 5 5}$ & 0.497 & 0.324 & 0.430 \\
\cline { 2 - 6 } & PU2 & $\mathbf{0 . 7 8 6}$ & 0.324 & 0.183 & 0.325 \\
\cline { 2 - 6 } & PU3 & $\mathbf{0 . 6 2 1}$ & 0.183 & 0.289 & 0.155 \\
\cline { 2 - 6 } & PU4 & $\mathbf{0 . 7 3 3}$ & 0.289 & 0.321 & 0.422 \\
\hline \multirow{5}{*}{ Perceived Ease of Use } & PEU1 & 0.108 & $\mathbf{0 . 7 6 8}$ & 0.455 & 0.305 \\
\cline { 2 - 6 } & PEU2 & 0.283 & $\mathbf{0 . 6 1 5}$ & 0.313 & 0.199 \\
\cline { 2 - 6 } & PEU3 & 0.309 & $\mathbf{0 . 7 3 6}$ & 0.129 & 0.329 \\
\cline { 2 - 6 } & PEU4 & 0.121 & $\mathbf{0 . 7 0 2}$ & 0.211 & 0.110 \\
\cline { 2 - 6 } & PEU5 & 0.324 & $\mathbf{0 . 6 2 2}$ & 0.406 & 0.215 \\
\hline \multirow{5}{*}{ Trust } & TR1 & 0.253 & 0.244 & $\mathbf{0 . 6 6 8}$ & 0.364 \\
\cline { 2 - 6 } & TR2 & 0.179 & 0.360 & $\mathbf{0 . 6 4 9}$ & 0.251 \\
\cline { 2 - 6 } & TR3 & 0.326 & 0.421 & $\mathbf{0 . 6 0 9}$ & 0.109 \\
\cline { 2 - 6 } & TR4 & 0.212 & 0.250 & $\mathbf{0 . 6 8 0}$ & 0.121 \\
\cline { 2 - 6 } Consumer mobile online shopping & CMOS1 & 0.324 & 0.324 & 0.203 & $\mathbf{0 . 8 6 8}$ \\
\cline { 2 - 6 } & CMOS2 & 0.242 & 0.166 & 0.423 & $\mathbf{0 . 8 2 0}$ \\
\cline { 2 - 6 } & CMOS3 & 0.301 & 0.428 & 0.103 & $\mathbf{0 . 7 5 6}$ \\
\cline { 2 - 6 } & CMOS4 & 0.201 & 0.165 & 0.291 & $\mathbf{0 . 8 4 8}$ \\
\cline { 2 - 6 } & CMOS5 & 0.402 & 0.318 & 0.450 & $\mathbf{0 . 6 4 3}$ \\
\hline
\end{tabular}

Table 2. Convergent validity

\begin{tabular}{|c|c|c|c|c|c|}
\hline Variables & Items & Loadings & $\mathbf{C R}_{\mathrm{a}}$ & Cronbach's Alpha & $\mathbf{A V E}_{\mathrm{b}}$ \\
\hline \multirow{4}{*}{ Perceived Usefulness } & PU1 & 0.655 & \multirow{4}{*}{0.736} & \multirow{4}{*}{0.709} & \multirow{4}{*}{0.578} \\
\hline & PU2 & 0.786 & & & \\
\hline & PU3 & 0.621 & & & \\
\hline & PU4 & 0.733 & & & \\
\hline \multirow{5}{*}{ Perceived Ease of Use } & PEU1 & 0.768 & \multirow{5}{*}{0.824} & \multirow{5}{*}{0.725} & \multirow{5}{*}{0.515} \\
\hline & PEU2 & 0.615 & & & \\
\hline & PEU3 & 0.736 & & & \\
\hline & PEU4 & 0.702 & & & \\
\hline & PEU5 & 0.622 & & & \\
\hline \multirow{4}{*}{ Trust } & TR1 & 0.668 & \multirow{4}{*}{0.865} & \multirow{4}{*}{0.742} & \multirow{4}{*}{0.602} \\
\hline & TR2 & 0.649 & & & \\
\hline & TR3 & 0.609 & & & \\
\hline & TR4 & 0.680 & & & \\
\hline \multirow{5}{*}{ Consumer mobile online shopping } & CMOS1 & 0.868 & \multirow{5}{*}{0.844} & \multirow{5}{*}{0.809} & \multirow{5}{*}{0.571} \\
\hline & CMOS2 & 0.820 & & & \\
\hline & CMOS3 & 0.756 & & & \\
\hline & CMOS4 & 0.848 & & & \\
\hline & CMOS5 & 0.643 & & & \\
\hline
\end{tabular}

\section{Conclusion, Limitation and Recommendations}

The study aimed and investigated how technology awareness and intention to use can increase mobile online shopping. The study sampled graduates of business 
administration colleges whether graduated or still a student from 4 different cities. The research founds a clear link between users' conducting mobile purchase and perceived usefulness, perceived ease of use and trust. The conclusions of this research have important implications for the development and refinement of mobile online shopping. Individual differences in adopting m-online shopping affect differently the perceived usefulness and perceived ease of use and trust. From the academic aspect, Future practitioners' need to focus more on analyzing external variables into individual variations and technology-related constructs and integrated them into the proposed analysis model, moreover, next practitioners can make extra investigate in other variables such as responsiveness, perceived risk and delivery time. Furthermore, this research supervises directions for future research regarding the classification of $\mathrm{m}$ online shopper types. The researchers suggest expanding the sample for multiple institutions and business to compare how users in different institutions and schools perceive their technology awareness, adoption to use such mobile online shopping and m-service facilities.

\section{$6 \quad$ References}

[1] Abu-AlSondos, I. A., \& Salameh, A. A. M. (2020). The effect of system quality and service quality toward using m-commerce service, based on consumer perspective. Management Science Letters, 10(11), 2589-2596. https://doi.org/10.5267/j.msl.2020.3.035

[2] Abu-Shanab, E. A. (2014). Antecedents of trust in e-government services: an empirical test in Jordan. Transforming Government: People, Process and Policy. https://doi.org/10. 1108/tg-08-2013-0027

[3] Abu-Shanab, E. A. (2017). E-government familiarity influence on Jordanians' perceptions. Telematics and Informatics, 34(1), 103-113. d https://doi.org/10.1016/j.tele.2016.05.001

[4] Akkucuk, U., \& Esmaeili, J. (2016). The Impact of Brands on Consumer Buying Behavior. International Journal of Research in Business and Social Science (2147-4478), 5(4), 1-16. https://doi.org/10.20525/ijrbs.v5i4.551

[5] Algharabat, R. S., Zamil, A. M., \& Vasista, T. (2015). The Influence of Retailer Enterprise Marketing Information System on Bullwhip Effect. International Journal of Business and Management, 10(3), 237. https://doi.org/10.5539/ijbm.v10n3p237

[6] Alkafagi, A., Salameh, A. A. M., \& Abu-AlSondos, I. A. (2019). The importance of individual technology factors for adoption of internet banking. European Journal of Business and Management, 11(36), 1-8. https://doi.org/10.7176/ejbm/11-36-01

[7] Areiqat, A. Y., Mahrakani, N. J., Zamil, A. M., \& Abu-Rumman, A. (2019). The Role of Strategies for Promoting Relations between Banks and Customers, and Their Impact on Customer Retention and the Market Share of Jordanian Commercial Banks. Academy of Accounting and Financial Studies Journal, 23(5), 1-10.

[8] Asmara, S., Sis, R. L., \& Yusuf, M. (2020). The Use of Online Marketplace Websites in Indonesia: A Study of Consumers' Motives and Gratification. International Journal of Interactive Mobile Technologies, 14(7), 133-148. https://doi.org/10.3991/ijim.v14i07. $\underline{11385}$

[9] Azmi, A., Ang, Y. D., \& Talib, S. A. (2016). Trust and justice in the adoption of a welfare e-payment system. Transforming Government: People, Process and Policy. https://doi.org/10.1108/tg-09-2015-0037 
[10] Barclay, D., Higgings, C., \& Thompson, R. (1995). The partial least squares (PLS) approach to casual modeling: Personal computer adoption and use as an illustration. Technology Studies, 2: 285-309, 1995. Hypothesis Testing. View at.

[11] Belanche, D., Casaló, L. V., \& Guinalíu, M. (2012). Website usability, consumer satisfaction and the intention to use a website: The moderating effect of perceived risk. Journal of retailing and consumer services, 19(1), 124-132. https://doi.org/10.1016/j.jretconser. 2011.11.001

[12] Belanger, F., Hiller, J. S., \& Smith, W. J. (2002). Trustworthiness in electronic commerce: the role of privacy, security, and site attributes. The Journal of Strategic Information Systems, 11(3-4), 245-270. https://doi.org/10.1016/s0963-8687(02)00018-5

[13] Biedenbach, G., \& Marell, A. (2010). The impact of customer experience on brand equity in a business-to-business services setting. Journal of Brand Management, 17(6), 446-458. https://doi.org/10.1057/bm.2009.37

[14] Dost, M. K., Illyas, M., \& Abdul Rehman, C. (2015). Online shopping trends and its effects on consumer buying behavior: A case study of young generation of Pakistan. NG-Journal of Social Development, 417(3868), 1-22. https://doi.org/10.12816/0032077

[15] Chow, W. S., \& Chan, L. S. (2008). Social network, social trust and shared goals in organizational knowledge sharing. Information \& Management, 45(7), 458-465. https://doi.org/10.1016/j.im.2008.06.007

[16] Davis, F. D. (1989). Perceived usefulness, perceived ease of use, and user acceptance of information technology. MIS quarterly, 319-340. https://doi.org/10.2307/249008

[17] Fornell, C., \& Larcker, D. F. (1981). Evaluating structural equation models with unobservable variables and measurement error. Journal of marketing research, 18(1), 39-50. https://doi.org/10.1177/002224378101800104

[18] Hair, J. F., Anderson, R. E., Babin, B. J., \& Black, W. C. (2010). Multivariate data analysis: A global perspective (Vol. 7). In: Upper Saddle River, NJ: Pearson.

[19] Hausman, A. V., \& Siekpe, J. S. (2009). The effect of web interface features on consumer online purchase intentions. Journal of business research, 62(1), 5-13. https://doi.org/10.1016/j.jbusres.2008.01.018

[20] Kevin. (2019). Consumer behaviour towards online shopping. Retrieved from https://medium.com/@eyorekon.kevin/consumer-behaviour-towards-online-shopping$1953679 f d 26 a$

[21] Kibet, K. A. (2016). A study of consumer behavior towards online shopping in Kenya: Case of Nairobi County. University of Nairobi,

[22] Minnaar, P., Mototo, L., \& Chuchu, T. (2020). An Analysis of the Intention of Consumers to Adopt Branded Mobile Applications in South Africa. International Journal of Interactive Mobile Technologies, 14(4), 138-151. https://doi.org/10.3991/ijim.v14i04.10602

[23] Omonedo, P., \& Bocij, P. (2014). E-commerce versus m-commerce: Where is the dividing line. International Journal of Social, Behavioural, Educational, Business and Industrial Engineering, 8(11), 3610-3615.

[24] Pratyaksa, P. (2015). The Influence of Convenience, Ease of Use and Security on Customer Satisfaction (Study on Mandiri Internet Banking at Mandiri Bank Surabaya Commercial Branch). Jurnal Administrasi Bisnis, 23(2).

[25] Rosqvist, L. S., \& Hiselius, L. W. (2016). Online shopping habits and the potential for reductions in carbon dioxide emissions from passenger transport. Journal of Cleaner Production, 131, 163-169. https://doi.org/10.1016/j.jclepro.2016.05.054

[26] Salameh, A. A. M., Ahmad, H., Zulhumadi, F., \& Abubakar, F. M. (2018). Relationships between system quality, service quality, and customer satisfaction. Journal of Systems and Information Technology, 20(1), 73-102. https://doi.org/10.1108/jsit-03-2017-0016 
Paper -Encouraging Consumers to Make Online Purchases Using Mobile Applications...

[27] Salameh, A. A. M., \& Hassan, S. B. (2015). Measuring service quality in m-commerce context: A conceptual model. International Journal of Scientific and Research Publications, 5(3), 1-9.

[28] Santhi, V., \& Gopal, L. N. (2018). The Consumer Behaviour towards Online Shopping in Coimbatore city-An Exploratory study. International Journal of Pure and Applied Mathematics, 120(5), 1459-1488.

[29] Selvamani, M., \& Vidya, P. (2019). Consumer Behaviour Towards Online Shopping - an Analysis with Product Dimensions. International Journal of Innovative Technology and Exploring Engineering, 8(12S), 511-514. https://doi.org/10.35940/ijitee.11127.108 $\underline{12 \mathrm{~s} 19}$

[30] Sultan, M. U., \& Uddin, M. (2011). Consumers' Attitude towards Online Shopping: Factors influencing Gotland consumers to shop online. In. https://doi.org/10.2139/ssrn.3450062

[31] Wongkhamdi, T., Cooharojananone, N., \& Khlaisang, J. (2020). E-Commerce Competence Assessment Mobile Application Development for SMEs in Thailand. International Journal of Interactive Mobile Technologies, 14(11), 48-75. https://doi.org/10.3991/ijim.v14i11. 11358

[32] Zamil, A. M. (2011). Customer relationship management: a strategy to sustain the organization's name and products in the customers' minds. European Journal of Social Sciences, 22(3), 451-459.

\section{$7 \quad$ Authors}

Dr. Ahmad M. A. Zamil is an Associate Professor, Department of Marketing, College of Business Administration, Prince Sattam Bin Abdulaziz University, AlKharj, KSA. His interested areas include: Marketing management, E-marketing, Retail Marketing, Consumer Behavior, He has 24 years of progressive experience of teaching and research in marketing specialization in Jordan and Saudi Arabia. Email: am.zamil@psau.edu.sa

Dr. Ibrahim Abu-AISondos is an Assistant Professor of Management Information Systems (MIS) in the college of administrative sciences, Applied Science University (ASU), Kingdome of Bahrain since 2019 and the current Programme leader of bachelor ofManagement Information Systems (BMIS). His research interest includes Knowledge Management (KM), IT-Business Strategic Alignment, E-Business,ECommerce, Mobile Commerce. Email: Ibrahim.abualsondos@asu.edu.bh

Dr. Anas A. Salameh is an Assistant Professor, Department of Management Information Systems, College of Business Administration, Prince Sattam Bin Abdulaziz University since 2016 and the current deputy director of the students' activities committee as well he is a member of the exams scheduling committee, PSAU.His major research interest focusing on the area such as e-commerce (mcommerce), e-business, e-marketing, technology acceptance / adoption, e-learning, eCRM, service quality, and he evaluated service quality in many areas related to eservices aspects. Email: $\underline{\text { a.salameh@psau.edu.sa }}$

Article submitted 2020-06-25. Resubmitted 2020-07-26. Final acceptance 2020-07-28. Final version published as submitted by the authors. 